\title{
The influence of various products used during growing season on head cabbage health after of long-term storage
}

\author{
Wpływ różnych preparatów stosowanych w okresie wegetacji \\ na zdrowotność główek kapusty głowiastej \\ po okresie długotrwałego ich przechowywania
}

\author{
Agnieszka Włodarek*, Ewa Badełek
}

\section{Summary}

The aim of the this study was to examine the effect of the pre-harvest protection of head cabbage using products containing: calcium + nanoparticles of silver, silver chitosan, foliar fertilizer containing $\mathrm{P}_{2} \mathrm{O}_{5}, \mathrm{Mg}, \mathrm{CaO}$, trifloxystrobin + tebukonazol, and piraclostrobin + boskalid to limit grey mould and examine the quality of heads after long-term storage. The studies were conducted in 2014/2015 and 2015/2016 at the Research Institute of Horticulture in Skierniewice. Cabbage was protected throughout the vegetation season and the last spraying was done 7 days before harvest. Cabbage heads were stored for 5 months in cool room at $0^{\circ} \mathrm{C}$ and relative humidity 90-95\%. The infection by Botrytis cinerea was natural. Most of the tested substances gave a positive influence on health and quality of stored cabbage heads. The best effectiveness against grey mould after long term storage showed conventional products containing: piraclostrobin + boskalid and trifloxystrobin + tebukonazol but other products showed variable efficiency.

Key words: head cabbage, Botrytis cinerea, pre-harvest treatment, long-term storage

\section{Streszczenie}

Celem przeprowadzonych badań było określenie wpływu przedzbiorczej ochrony kapusty głowiastej z wykorzystaniem środków zawierających: wapń + nanocząsteczki srebra, chitozan srebra, nawozów dolistnych zawierających $\mathrm{P}_{2} \mathrm{O}_{5}, \mathrm{Mg}, \mathrm{CaO}$ i trifloksystrobinę + tebukonazol oraz piraklostrobinę + boskalid na ograniczenie szarej pleśni oraz jakość główek po okresie ich długotrwałego przechowania. Doświadczenia prowadzone były w latach 2014/2015 i 2015/2016 w Instytucie Ogrodnictwa w Skierniewicach. Kapustę chroniono w okresie wegetacji, a ostatni zabieg ochrony wykonano 7 dni przed zbiorem. Główki kapusty były przechowywane w chłodni przez 5 miesięcy w temperaturze $0^{\circ} \mathrm{C}$ i wilgotności względnej 90-95\%. Infekcja Botrytis cinerea była naturalna. Większość testowanych środków wykazała pozytywny wpływ na zdrowotność i jakość przechowywanych główek kapusty. Najwyższą efektywność w ograniczaniu szarej pleśni po okresie długotrwałego przechowywania wykazały preparaty konwencjonalne zawierające: piraklostrobinę + boskalid i trifloksystrobinę + tebukonazol, natomiast pozostałe środki odznaczały się zróżnicowaną skutecznością.

Słowa kluczowe: kapusta głowiasta, Botrytis cinerea, ochrona przedzbiorcza, długotrwałe przechowywanie

\section{Instytut Ogrodnictwa}

Konstytucji 3 Maja 1/3, 96-100 Skierniewice

*corresponding author: agnieszka.wlodarek@inhort.pl

ORCID: 0000-0001-6501-9317 


\section{Wstęp / Introduction}

Kapusta głowiasta (Brassica oleracea var. capitata f. alba) należy do warzyw kapustowatych powszechnie uprawianych w Polsce. Jest bogatym źródłem witaminy C, soli potasu, wapnia, magnezu i żelaza oraz witamin (B1, B2, B6, E, H, K, U), a także fitoncydów - naturalnych substancji wydzielanych przez rośliny wyższe, hamujących rozwój mikroorganizmów chorobotwórczych. Jest to dwuletnia roślina, która w pierwszym roku uprawy tworzy część jadalną tzw. „głowę" - skrócony pęd ze zwiniętymi, dużymi liśćmi, a w drugim roku tworzy pędy nasienne $\mathrm{z}$ owocami w postaci łuszczyn. Jej areał w Polsce w 2018 roku wynosił blisko 19,5 tysiąca ha. W celu uzyskania zdrowych i jakościowo dobrych główek kapusty po okresie przechowywania, należy uwzględnić wiele czynników: dobór właściwej odmiany przydatnej do długotrwałego przechowywania, prawidłową ochronę plantacji przed agrofagami w okresie wegetacji, właściwe nawożenie i nawadnianie plantacji, jak również przestrzeganie optymalnego terminu zbioru (Adamicki i Czerko 2002; Adamicki i wsp. 2005). Na parametry fazy dojrzałości zbiorczej składają się: właściwy kształt, wielkość i waga (Agblor i Waterer 2001). Do przechowania należy przeznaczać główki zdrowe, zbite, z głąbem przyciętym na wysokość 2-3 cm i bez uszkodzeń mechanicznych. Po zbiorze roślin wymagane jest ich szybkie schłodzenie w celu zachowania wysokiej zdrowotności i w efekcie ograniczenia strat. Temperatura powietrza $0^{\circ} \mathrm{C}$ i wilgotność względna 90-95\% są optymalne dla przechowywania główek. W takich warunkach kapustę można przechowywać przez okres 6-8 miesięcy (Adamicki i Czerko 2002). Wiele czynników wpływa na zdrowotność główek kapusty w okresie długotrwałego przechowania, jednak największe zagrożenie stwarza polifagiczny grzyb - Botrytis cinerea Pers. sprawca szarej pleśni (Geeson i Browne 1980). Patogen ten może być powodem wysokich strat poprzez obniżenie jakości i wielkości plonu handlowego (Robak i wsp. 2007; Survilienė i wsp. 2010; Osher i wsp. 2018).

Obowiązujące od 1 stycznia 2014 roku zasady integrowanej ochrony roślin nakładają na wszystkich profesjonalnych użytkowników środków ochrony roślin konieczność stosowania m.in. alternatywnych metod ochrony opartych o środki niechemiczne, takich jak np. środki biologiczne, pochodzenia naturalnego, stymulatory odporności, wzrostu i rozwoju, a także nawozy (Lipa i Pruszyński 2010). W badaniach prowadzonych w Instytucie Ogrodnictwa od wielu lat podejmowane są próby unowocześnienia przedzbiorczej ochrony kapusty głowiastej przed patogenami z wykorzystaniem środków przyjaznych środowisku i mogących korzystnie wpływać na zdrowotność główek w okresie przechowania. Związane jest to z obserwowanym od kilku lat stałym procesem uodparniania się agrofagów na stosowane substancje czynne fungicydów. W celu zapobiegania temu zjawisku należy podejmować próby wprowadzania do ochrony środków o odmiennych mechanizmach działania na zwalczane patogeny (Zamojska i Malinowski 2012).

Dotychczasowe badania potwierdziły wysoką efektywność jedno- i dwuskładnikowych fungicydów z grup chemicznych - metoksyakrylany, chloronitryle, pirydynokarboksyamidy i oksyiminoacetaty: Amistar 250 SC, Amistar Opti 480 SC, Signum 33 WG, Zato 50 WG oraz środków pochodzenia naturalnego: Timorex Gold 24 EC, Grevit 200 SL i ekstraktu z truskawki, w ograniczaniu chorób powodowanych przez grzyby po okresie długotrwałego przechowania korzeni marchwi, selera, pietruszki, główek kapusty głowiastej i pekińskiej (Ostrowska i wsp. 2010a, b; Włodarek i wsp. 2013, 2015).

Przeprowadzone badania miały na celu określenie wpływu różnych środków stosowanych podczas wegetacji kapusty głowiastej na zdrowotność główek po okresie długotrwałego przechowywania. Założono, że środki te ograniczą nasilenie objawów szarej pleśni ( $B$. cinerea), co wpłynie pozytywnie na jakość przechowywanych główek i zmniejszy straty plonu handlowego.

\section{Materiały i metody / Materials and methods}

Kapustę głowiastą do długotrwałego przechowania i oceny jej zdrowotności po 5-miesięcznym okresie przechowywania, uprawiano na polu doświadczalnym Instytutu Ogrodnictwa, w latach 2014 i 2015. W tym celu, rozsadę kapusty odmiany Jaguar F1 wysadzano na poletka o powierzchni $10 \mathrm{~m}^{2}$ (EPPO PP/121(2) 2004) metodą losowanych bloków, w układzie jednoczynnikowym w czterech powtórzeniach. Rośliny wysadzano w rozstawie rzędów $50 \mathrm{~cm}$ i $50 \mathrm{~cm}$ w rzędzie (2 rośliny na metr bieżący rzędu), w fazie rozwojowej BBCH 13-14 (3-4 liście właściwe), w terminach: 6 czerwca 2014 i 3 czerwca 2015 roku. Do ochrony kapusty przed chwastami stosowano Devrinol $450 \mathrm{SC}$ w dawce 2,5 1/ha, a w okresie wegetacji chwasty dodatkowo usuwano ręcznie. Wszystkie zabiegi ochrony i nawożenia roślin prowadzono zgodnie z zasadami agrotechnicznymi i dobrą praktyką ochrony roślin (Pruszyński i Wolny 2007). Przed sadzeniem rozsady wykonano analizę gleby pod kątem zawartości składników pokarmowych, a następnie nawożono pole według zaleceń nawozowych, stosując następujące nawożenie mineralne: $60 \mathrm{~kg} / \mathrm{ha} \mathrm{N}$, $60 \mathrm{~kg} / \mathrm{ha} \mathrm{P}_{2} \mathrm{O}_{5}$ i $100 \mathrm{~kg} \mathrm{~K} \mathrm{O}_{2}$. Siedem tygodni po sadzeniu roślin wykonano nawożenie pogłówne nawozem azotowym (saletrzak) w dawce $60 \mathrm{~kg} / \mathrm{ha} \mathrm{N}$. W obydwu latach wegetacji kapustę chroniono 2-krotnie przed szkodnikami insektycydami: Karate Zeon $050 \mathrm{SC}$ w dawce 0,12 1/ha i Proteus 110 OD w dawce 0,75 1/ha.

W latach 2014 i 2015, w ochronie przed patogenami, w okresie wegetacji kapusty stosowano następujące preparaty: Viflo Cal S mający w składzie $6 \%$ wapnia w połączeniu z 25 ppm cząsteczkami nanosrebra, Fosfiron Mg za- 
wierający $40 \%$ fosforu w formie $\mathrm{P}_{2} \mathrm{O}_{5}, 10 \%$ magnezu $(\mathrm{Mg})$ i $0,5 \%$ wapnia $(\mathrm{CaO})$, Viflo Chitosal Silver zawierający chitozan srebra oraz fungicydy konwencjonalne - Nativo 75 WG zawierający 50\% tebukonazolu i 25\% trifloksystrobiny oraz Signum 33 WG, mający w składzie mieszaninę boskalidu o zawartości $26,7 \%$ i piraklostrobiny o zawartości $6,7 \% \mathrm{w}$ dawkach podanych w tabeli 1 .

W okresie wegetacji kapusty, w latach 2014 i 2015, wykonano odpowiednio, 3 i 2 zabiegi badanymi środkami, w odstępach co 7-21 dni. Ostatnie zabiegi ochrony przed planowanym zbiorem i umieszczeniem główek kapusty w przechowalni dokonano: 8.10.2014 i 16.10.2015. Kontrolę stanowiły rośliny kapusty nawożone, ale niechronione w okresie wegetacji przy użyciu fungicydów. Technika opryskiwania była prowadzona zgodnie z normami EPPO PP 1/181(4) (2012). Kapustę zbierano w fazie dojrzałości zbiorczej w obydwu doświadczeniach 23 października, a podczas zbioru pobierano próby do przechowywania.

Zdrowe i nieuszkodzone główki kapusty transportowano do chłodni Instytutu Ogrodnictwa i składowano w drewnianych skrzyniopaletach, w których poszczególne kombinacje były oddzielone agrowłókniną. Doświadczenia w przechowalni założono w 3 powtórzeniach, każde po 20 główek.
Kapustę w obu sezonach (2014/2015 i 2015/2016) przechowywano przez okres 5 miesięcy, w temperaturze $0^{\circ} \mathrm{C}$ i wilgotności względnej 90-95\%.

Po okresie przechowania określano nasilenie szarej pleśni szacując procent porażonej powierzchni główek kapusty w obiekcie według 8-stopniowej skali bonitacyjnej: $0^{\circ}$ - brak objawów chorobowych, $1^{\circ}$ - do $1 \%$ porażonej powierzchni, $2^{\circ}$ - od 2 do $6 \%$ porażonej powierzchni, $3^{\circ}$ - od 7 do $15 \%$ porażonej powierzchni, $4^{\circ}$ - od 16 do $30 \%$ porażonej powierzchni, $5^{\circ}$ - od 31 do $50 \%$ porażonej powierzchni, $6^{\circ}-$ od 51 do $80 \%$ porażonej powierzchni, $7^{\circ}-$ od 81 do 100\% porażonej powierzchni (Sobolewski i Robak 2004). Główki kapusty sortowano na zdrowe główki handlowe i z objawami chorób. Masę kapusty handlowej określano po usunięciu liści zwiędłych, żółtych i zasiedlonych przez mikroorganizmy. Otrzymane wyniki opracowano statystycznie posługując się metodą analizy wariancji. Do oceny różnic między średnimi użyto testu Newmana-Keulsa, przyjmując poziom istotności 5\%. Skuteczność badanych środków obliczono za pomocą wzoru Abbotta (Abbott 1925).

W celu weryfikacji sprawcy choroby, z porażonych główek kapusty pobrano skrawki liści wskazujące na obecność $B$. cinerea. Fragmenty wielkości $5 \mathrm{~mm}$ odkażano

Tabela 1. Ocena biologicznej skuteczności testowanych środków stosowanych w okresie wegetacji na zdrowotność główek kapusty głowiastej w sezonach przechowalniczych 2014/2015 i 2015/2016

Table 1. Evaluation of biological efficiency of tested products in pre-harvest protection of head cabbage on their health during storage seasons 2014/2015 and 2015/2016

\begin{tabular}{|c|c|c|c|c|c|c|c|c|c|c|c|}
\hline \multirow{3}{*}{$\begin{array}{l}\text { Badane środki } \\
\text { Treatments }\end{array}$} & \multirow{3}{*}{$\begin{array}{l}\text { Substancja } \\
\text { czynna } \\
\text { Active } \\
\text { substance }\end{array}$} & \multirow{3}{*}{$\begin{array}{l}\text { Dawka } \\
\text { środka } \\
\text { Rate of } \\
\text { product } \\
{[1, \mathrm{~kg} / \mathrm{ha}]}\end{array}$} & \multicolumn{6}{|c|}{$\begin{array}{c}\text { Szara pleśń - Grey mould } \\
\text { Botrytis cinerea }\end{array}$} & \multirow{2}{*}{\multicolumn{3}{|c|}{$\begin{array}{c}\text { Główki handlowe } \\
\text { Marketable heads } \\
{[\%]}\end{array}$}} \\
\hline & & & \multicolumn{3}{|c|}{$\begin{array}{l}\text { średni \% porażonej } \\
\text { powierzchni główek } \\
\text { the average percentage } \\
\text { of infected heads }\end{array}$} & \multicolumn{3}{|c|}{$\begin{array}{c}\text { skuteczność* }^{*} \\
\text { effectiveness } \\
{[\%]}\end{array}$} & & & \\
\hline & & & $\begin{array}{l}2014 / \\
2015^{1}\end{array}$ & $\begin{array}{l}2015 / \\
2016^{2}\end{array}$ & $\begin{array}{c}\text { średnia } \\
\text { mean }\end{array}$ & $\begin{array}{l}2014 / \\
2015^{1}\end{array}$ & $\begin{array}{l}2015 / \\
2016^{2}\end{array}$ & $\begin{array}{c}\text { średnia } \\
\text { mean }\end{array}$ & $\begin{array}{l}2014 / \\
2015^{1}\end{array}$ & $\begin{array}{l}2015 / \\
2016^{2}\end{array}$ & $\begin{array}{c}\text { średnia } \\
\text { mean }\end{array}$ \\
\hline $\begin{array}{l}\text { Kontrola } \\
\text { Check }\end{array}$ & - & - & $23,2 \mathrm{a}$ & $14,4 \mathrm{a}$ & 18,8 & - & - & - & $52,3 \mathrm{a}$ & 57,9 a & 55,1 \\
\hline Signum 33 WG & $\begin{array}{l}\text { piraclostrobin }+ \\
\text { boskalid }\end{array}$ & 1,0 & $2,5 \mathrm{~d}$ & $4,0 \mathrm{c}$ & 3,25 & 89,2 & 97,2 & 93,2 & $78,2 \mathrm{a}$ & 51,9 a & 65,1 \\
\hline Nativo 75 WG & $\begin{array}{l}\text { trifloxystrobin }+ \\
\text { tebukonazol }\end{array}$ & 0,36 & $6,6 \mathrm{c}$ & $3,7 \mathrm{c}$ & 5,15 & 71,6 & 74,3 & 72,95 & $61,7 \mathrm{a}$ & $54,2 \mathrm{a}$ & 58,0 \\
\hline Viflo Cal S & $\begin{array}{l}\text { calcium }+ \\
\text { nanoparticles } \\
\text { of silver }\end{array}$ & 2,8 & $6,3 \mathrm{c}$ & $7,7 \mathrm{~b}$ & 7,0 & 72,8 & 46,5 & 59,65 & $59,6 \mathrm{a}$ & $52,5 \mathrm{a}$ & 56,1 \\
\hline $\begin{array}{l}\text { Viflo Chitosal } \\
\text { Silver }\end{array}$ & silver chitosan & 2,8 & $1,4 \mathrm{~d}$ & $9,1 \mathrm{~b}$ & 5,25 & 94,0 & 36,8 & 65,4 & $68,9 \mathrm{a}$ & 53,2 a & 61,1 \\
\hline Fosfiron $\mathrm{Mg}$ & $\begin{array}{c}\text { foliar fertilizer } \\
\left(\mathrm{P}_{2} \mathrm{O}_{5}, \mathrm{Mg}, \mathrm{CaO}\right)\end{array}$ & 2,8 & $12,2 \mathrm{~b}$ & $3,4 \mathrm{c}$ & 7,8 & 47,4 & 76,4 & 61,9 & $57,0 \mathrm{a}$ & $60,3 \mathrm{a}$ & 58,7 \\
\hline
\end{tabular}

'Okres przechowania: 23.10.2014-24.03.2015 - Storage period: 23.10.2014-24.03.2015

${ }^{2}$ Okres przechowania: 23.10.2015-31.03.2016 - Storage period: 23.10.2015-31.03.2016

Test Newmana-Keulsa dla $\mathrm{p}=0,05-$ Newman-Keul's test $(\mathrm{p}=0.05)$

Wartości liczbowe oznaczone tą samą literą nie różnią się istotnie przy $\mathrm{p}=0,05$ - Values in columns followed by the same letter are not significantly different $(\mathrm{p}=0.05)$

*Skuteczność obliczona według wzoru Abbotta - Efficacy of product calculated by Abbott's formula 
w podchlorynie sodu i wykładano na szalki Petriego o średnicy $90 \mathrm{~mm}$ (po 20 sztuk) z pożywką ziemniaczano-glukozową (PDA - Potato Dextrose Agar). Po 72 godzinach hodowli w temperaturze $25^{\circ} \mathrm{C}$, w ciemności, wyrastające fragmenty strzępek wokół wyłożonych części porażonych liści, przeszczepiano na skosy z PDA. Po 7 dniach inkubacji wybrano kultury reprezentacyjne, które następnie oznaczano do rodzaju i gatunku na podstawie ich cech morfologicznych (Kochman 1967; Marcinkowska 2003; Kryczyński i Weber 2011; Rataj-Guranowska i Pukacka 2012).

\section{Wyniki i dyskusja / Results and discussion}

Po 5-miesięcznym okresie przechowania, najwyższe nasilenie szarej pleśni, w obydwu doświadczeniach, odnotowano w obiektach kontrolnych (tab. 1), gdzie średni procent porażonej powierzchni główek wynosił 23,2\% (po sezonie przechowalniczym 2014/2015) i 14,4\% (po sezonie przechowalniczym 2015/2016). Niski procent porażenia uzyskano w kombinacjach, gdzie w okresie wegetacji stosowano środek zawierający piraklostrobinę i boskalid oraz preparat zawierający tebukonazol i trifloksystrobinę, odpowiednio 2,5 i 6,6\% po okresie przechowania 2014/2015 oraz 4,0 i 3,7\% po okresie przechowania 2015/2016. Środki te pozytywnie wpłynęły na plon handlowy główek po sezonie przechowalniczym 2014/2015. W kolejnym roku badań odnotowano jednak niższy procent główek handlowych niż w kombinacji kontrolnej w porównaniu do sezonu 2014/2015. Uzyskane wyniki są zbieżne z rezultatami badań Hauke i wsp. (2004) oraz Survilienè i wsp. (2010), którzy potwierdzili wysoką skuteczność piraklostrobiny i boskalidu w zwalczaniu $B$. cinerea na kapuście białej głowiastej oraz owocach truskawki. Natomiast testowana mieszanina tebukonazolu i trifloksystrobiny nie była dotychczas dopuszczona do ochrony kapusty przed szarą pleśnią w Polsce. Tebukonazol skutecznie redukuje wzrost grzybni i znacząco hamuje kiełkowanie zarodników B. cinerea wyizolowanego z liści truskawek (Kim i wsp. 2016). Doniesienia Saha i wsp. (2018) wskazują na wysoki wpływ trifloksystrobiny i tebukonazolu na hamowanie wzrostu grzybni Alternaria brassicae w warunkach in vitro, jak również, ograniczanie patogena w uprawie polowej kapusty.

$\mathrm{Z}$ dostępnej literatury wiadomo, że zastosowany w badaniach nawóz zawierający fosforyny - Fosfiron $\mathrm{Mg}$, może z jednej strony dostarczać składników pokarmowych (np. magnezu, wapnia), z drugiej przyczyniać się do ograniczania presji chorób powodowanych przez grzyby, co ma istotne znaczenie w integrowanej ochronie. Thao i Yamakawa (2009) podają, że fosforyny działają jak elicytory, które pomagają chronić rośliny poprzez stymulację szlaku kwasu szikimowego, podczas którego rośliny produkują i gromadzą w swoich tkankach fitoaleksyny umożliwiające im ochronę przed atakiem patogenów. W przypadku niniejszych badań
Fosfiron Mg okazał się skuteczny w ograniczaniu szarej pleśni w porównaniu do kontroli. Po sezonie 2014/2015, na przechowywanych główkach, gdzie w okresie wegetacji kapusty aplikowano nawóz, obserwowano symptomy powodowane przez sprawcę szarej pleśni na poziomie 12,2\%. Z kolei po okresie przechowalniczym 2015/2016 odnotowano znacznie niższe porażenie $(3,4 \%)$. Stwierdzono pozytywny wpływ nawozu Fosfiron Mg na wzrost udziału główek handlowych, który po obydwu badanych sezonach był istotnie wyższy niż w kontroli (tab. 1). Skuteczność działania fosforynów potwierdzili również Wild i wsp. (1998), którzy aplikowali fosforyny na uszkodzone i zainfekowane przez B. cinerea owoce jabłoni i zaobserwowali, że efektywnie redukują one objawy szarej pleśni.

$\mathrm{Z}$ informacji podanych przez producenta nawozu wzbogaconego wapniem i cząsteczkami srebra - Viflo Cal S, dowiadujemy się, że preparat ten wzmacnia odporność roślin na choroby przechowalnicze. W literaturze można również znaleźć wiele informacji o pozytywnym działaniu środków opartych na chitozanie, cząsteczkach srebra i wapnia w ochronie roślin. Zastosowane w przeprowadzonych badaniach preparaty zawierające cząsteczki srebra: Viflo Cal S i Viflo Chitozal Silver charakteryzowały się zróżnicowaną skutecznością ograniczania nasilenia szarej pleśni po obydwu sezonach przechowalniczych (tab. 1). Po 5-miesięcznym okresie przechowania w sezonie 2014/2015, odnotowano niższe porażenie główek przez $B$. cinerea (odpowiednio 6,3 i 1,4\%) oraz wyższy udział główek handlowych (odpowiednio 59,6 i 68,9\%) niż po kolejnym sezonie przechowalniczym (2015/2016), gdzie wielkość infekcji była na poziomie 7,7\% (Viflo Cal S) i 9,1\% (Viflo Chitosal Silver), a procentowy udział materiału handlowego był niższy niż w kombinacji kontrolnej. Skuteczność Viflo Chitosal Silver po okresie przechowania 2014/2015, była porównywalna do środka referencyjnego Signum $33 \mathrm{WG}$, ale wyniki te nie powtórzyły się w kolejnym roku badań. Z kolei skuteczność Viflo Cal S, po sezonie przechowalniczym 2014/2015, w zasadzie nie różniła się od fungicydu Nativo 75 WG i była niższa od środków Viflo Chitosal Silver i Signum 33 WG. Natomiast po okresie przechowywania 2015/2016, skuteczność Viflo Cal S była porównywalna do Viflo Chitosal Silver i wynosiła poniżej 50\%.

Grzegorzewska i Kowalska (2013) badały nanokoloidy srebra i stwierdziły, że ograniczały one wzrost Sclerotinia sclerotiorum na plastrach marchwi w temperaturze $25^{\circ} \mathrm{C}$, ale nie miały wpływu na wzrost grzybni $B$. cinerea na fragmentach liści kapusty głowiastej i łuskach mięsistych cebuli. Nie jest to zgodne $\mathrm{z}$ wynikami zawartymi w niniejszej pracy, gdzie stwierdzono, że środki zawierające nanocząsteczki srebra korzystnie wpływały na zdrowotność główek kapusty po 5-miesięcznym okresie przechowania. Przyczyną tego, może być fakt, że w ich składzie znajdują się także wapń i chitozan. W literaturze światowej znane są przykłady pozytywnego wpływu wapnia na hamowanie wzrostu $B$. cine- 
rea $\mathrm{w}$ warunkach laboratoryjnych oraz $\mathrm{w}$ uprawie hydroponicznej papryki (Yoon i wsp. 2010), a Chardonnet i wsp. (2000) zaobserwowali, że traktowanie jabłek wapniem ograniczało ich gnicie powodowane przez 3 izolaty $B$. cinerea. Praca Ahmeda (2017) potwierdza z kolei hamujące właściwości nanocząsteczek chitozanu i nanocząsteczek srebra w ograniczaniu Botrytis fabae. W testach laboratoryjnych autor zaobserwował, że liczba zarodników oraz masa grzybni patogena obniżała się wraz ze wzrostem stężenia badanych nanocząsteczek. Podobne wyniki autor uzyskał również w badaniach szklarniowych. Salem i wsp. (2019) wykazali pozytywny wpływ nanocząsteczek srebra na ograniczenie $B$. cinerea i polepszenie jędrności przechowywanych owoców pomidora.

Analiza mykologiczna porażonych główek kapusty po okresie długotrwałego przechowywania potwierdziła obecność $B$. cinerea.

Doskonalenie systemu integrowanej ochrony kapusty głowiastej przed chorobami wymaga ciągłych badań, w tym poszukiwania środków o różnych substancjach czynnych i odmiennych mechanizmach działania, które zabezpieczą rośliny przed patogenami zarówno w okresie wegetacji, jak i w okresie długotrwałego przechowania, a jednocześnie będą przyjazne środowisku i zdrowiu człowieka.

\section{Wnioski / Conclusions}

1. Zastosowane w okresie wegetacji kapusty głowiastej konwencjonalne środki chemiczne Signum 33 WG i Nativo 75 WG oraz Viflo Cal S, Viflo Chitosal Silver i Fosfiron $\mathrm{Mg}$ istotnie ograniczały porażenie główek przez $B$. cinerea po 5-mięsiecznym okresie przechowywania w obydwu sezonach przechowalniczych.

2. Środki Viflo Cal S, Viflo Chitosal Silver i Fosfiron Mg mogą być zalecane do wspomagania ochrony kapusty w okresie wegetacji w celu ograniczania nasilenia szarej pleśni.

\section{Literatura / References}

Abbott W.S. 1925. A method for computing the effectiveness of an insecticide. Journal of Economic Entomology 18 (2): 265-267. DOI: $10.1093 /$ jee/18.2.265a

Adamicki F., Czerko Z. 2002. Czynniki wpływające na trwałość przechowalniczą warzyw. s. 44-56. W: Przechowalnictwo warzyw i ziemniaka (F. Adamicki, Z. Czerko Z., red.). Państwowe Wydawnictwo Rolnicze i Leśne, Poznań, 324 ss. ISBN 83-09-01766-9.

Adamicki F., Dobrzański A., Felczyński K., Robak J., Szwejda J. 2005. Metodyka integrowanej produkcji marchwi. Państwowa Inspekcja Ochrony Roślin i Nasiennictwa, Warszawa, 34 ss.

Agblor S., Waterer D. 2001. Cabbage - post-harvest handling and storage. Canada-Saskatchewan Irrigation Diversification Centre.

Ahmed A.I.S. 2017. Chitosan and silver nanoparticles as control agents of some faba bean spot diseases. Journal of Plant Pathology \& Microbiology 8: 9. DOI: 10.4172/2157-7471.1000421

Chardonnet C.O., Sams C.E., Trigiano R.N., Conway W.S. 2000. Variability of three isolates of Botrytis cinerea. Affects the inhibitory effects of calcium on this fungus. Postharvetst Pathology and Mycotoxins 90 (7): 769-774. DOI: 10.1094/PHYTO.2000.90.7.769

EPPO PP 1/121(2) 2004. Efficacy evaluation of plant protection products. Fungicides and bacteriocides. Efficacy evaluation of fungicides. Leafspots of vegetables. EPPO Standards PP1 2nd ed.: 134-139.

EPPO PP 1/181(4) 2012. Efficacy evaluation of plant protection products. Conduct and reporting of efficacy evaluation trials, including good experimental practice. Bulletin OEPP/EPPO Bulletin 42 (3): 382-393. DOI: 10.1111/epp.2611

Geeson J.D., Browne K.M. 1980. Controlled atmosphere storage of white winter cabbage. Annals of Applied Biology 95 (2): $267-272$. DOI: $10.1111 / \mathrm{j} .1744-7348.1980 . t b 04746 . x$

Grzegorzewska M., Kowalska B. 2013. Wpływ nanokoloidów srebra i miedzi oraz nadtlenku wodoru na niektóre patogeny grzybowe warzyw. [The influence of nano-silver, nano-copper and hydrogen peroxide on vegetable pathogens]. Zeszyty Naukowe Instytutu Ogrodnictwa 21: 15-23.

Hauke K., Creemers P., Brugmans W., Van Laer S. 2004. Signum, a new fungicide with interesting properties in resistance management of fungal diseases in strawberries. Communications in Agricultural and Applied Biological Sciences 69 (4): 743-755.

http://www.agr.gc.ca/resources/prod/doc/pfra-arap/csidc-crdi/pdf/cabbage-chou_eng.pdf [dostęp: 17.02.2020].

Kim J.-O., Shin J.-H., Gumilang A., Chung K., Choi K.Y., Kim K.S. 2016. Effectiveness of different classes of fungicides on Botrytis cinerea causing gray mold on fruit and vegetables. The Plant Pathology Journal 32 (6): 570-574. DOI: 10.5423/PPJ.NT.05.2016.0114

Kochman J. 1967. Fitopatologia. Państwowe Wydawnictwo Rolnicze i Leśne, Warszawa, 686 ss.

Kryczyński S., Weber Z. 2011. Fitopatologia. Choroby roślin uprawnych. Tom 2. Powszechne Wydawnictwo Rolnicze i Leśne Sp. z o.o., Poznań, 464 ss.

Lipa J., Pruszyński S. 2010. Stan wykorzystania metod biologicznych w ochronie roślin w Polsce i na świecie. [Scale of use of biological methods in plant protection in Poland and in the world]. Progress in Plant Protection/Postępy w Ochronie Roślin 50 (3): $1033-1043$.

Marcinkowska J. 2003. Oznaczanie rodzajów grzybów ważnych w patologii roślin. Fundacja Rozwój SGGW, Warszawa, 328 ss.

Osher Y., Chalupowicz D., Maurer D., Ovadia-Sadeh A., Lurie S., Fallik E., Kenigsbuch D. 2018. Summer storage of cabbage. Postharvest Biology and Technology 145: 144-150. DOI: 10.1016/j.postharvbio.2018.07.006

Ostrowska A., Badełek E., Robak J. 2010a. Wpływ zrównoważonej ochrony przedzbiorczej kapusty głowiastej i pekińskiej przed chorobami na ich zdolność przechowalniczą. Ogólnopolska Naukowa Konferencja Warzywnicza - Postęp w integrowanej produkcji warzyw kapustowatych. Skierniewice, 21.10.2010: 51-52.

Ostrowska A., Robak J., Gidelska A. 2010b. Nowe możliwości przedzbiorczej ochrony warzyw kapustowatych z zastosowaniem nowoczesnych środków na ich zdolność przechowalniczą. [New possibilities preharvest protection of brassica vegetables using new products on their influence on long-term storage]. Progress in Plant Protection/Postępy w Ochronie Roślin 50 (2): 555-559.

Pruszyński S., Wolny S. 2007. Przewodnik dobrej praktyki ochrony roślin. Instytut Ochrony Roślin, Poznań, 80 ss. 
Rataj-Guranowska M., Pukacka A. 2012. Kompendium symptomów chorób roślin i morfologii ich sprawców. Instytut Ochrony Roślin - Państwowy Instytut Badawczy, Bank Patogenów Roślin i Badania ich Bioróżnorodności. Bogucki Wydawnictwo Naukowe, Poznań, 178 ss.

Robak J., Ostrowska A., Adamicki F. 2007. Nowe możliwości przed i pozbiorczej ochrony warzyw przed chorobami. [Effect of pre- and postharvest treatments on diseases control during storage of vegetables]. Progress in Plant Protection/Postępy w Ochronie Roślin 47 (2): 299-305.

Saha S., Hingmire S., Shabeer T.P.A., Banerjee K., Ashtekar N., Patil A., Rai A.B. 2018. Assessment of trifloxystrobin 25\% + tebuconazole 50\%-75 WG. Bioefficacy, safety and residue dynamics against leaf spot of cabbage. Chemical Science Review and Letters 7 (28): 867-874.

Salem E.A., Nawito M.A.S., A.E.-R.A.E.-R. Ahmed 2019. Effect of silver nano-patricles on gray mold of tomato fruits. Journal of Nanotechnology Research 1 (2): 108-118. DOI: 10.26502/jnr.2688-8521009

Sobolewski J., Robak J. 2004. Możliwości kompleksowej ochrony pomidora z wykorzystaniem nowych fungicydów i środków pochodzenia organicznego. [New products used for complex disease control on tomato growing in open field]. Progress in Plant Protection/Postępy w Ochronie Roślin 44 (2): 1105-1107.

Survilienė E., Valiuśkaite A., Duchovskienė L., Kavaliauskaite D. 2010. Influence of fungicide treatment on grey mould of cabbage. Vegetable Crops Research Bulletin 73: 133-142. DOI: 10.2478/v10032-010-0025-8

Thao H.T.B., Yamakawa T. 2009. Phosphite (phosphorous acid): fungicide, fertilizer or bio-stimulator? Soil Science and Plant Nutrition 55 (2): 228-234. DOI: 10.1111/j.1747-0765.2009.00365.x

Wild B.L., Wilson C.L., Winley E.L. 1998. Apple host defence reactions as affected by cycloheximide, phosphonate and citrus green mould, Penicillium digitatum. s. 155-161. W: Disease Resistance in Fruit. Proceedings of an International Workshop held at Chiang Mai, Thailand, 18-21 May 1997 (G.I. Johnson, E. Highley, D.C. Joyce, red.). Australian Centre for International Agricultural Research, Canberra, No. 80, 233 ss. ISBN 1863202145.

Włodarek A., Badełek E., Robak J. 2013. Wpływ nowych środków ochrony roślin stosowanych w czasie wegetacji na trwałość przechowalniczą warzyw korzeniowych. [The influence of new products used during growing season on storage potential of root vegetables]. Zeszyty Naukowe Instytutu Ogrodnictwa 21: 127-137.

Włodarek A., Badełek E., Robak J. 2015. Wpływ różnych środków stosowanych w okresie wegetacji selera na objawy miękkiej zgnilizny korzeni spichrzowych. [The influence of various products applied during the celeriac vegetation period on soft root rot]. Progress in Plant Protection/Postępy w Ochronie Roślin 55 (4): 386-390. DOI: 10.14199/ppp-2015-065

Yoon C.S., Yeoung Y.R., Kim B.S. 2010. The suppresive effects of calcium compounds against Botrytis cinerea in paprika. Korean Journal of Horticulture Science \& Technology 28 (6): 1072-1077.

Zamojska J., Malinowski H. 2012. Integrowana metoda ochrony roślin a odporność agrofagów na pestycydy w Polsce. [Integrated plant protection and pest resistance to pesticides in Poland]. Progress in Plant Protection/Postępy w Ochronie Roślin 52 (4): $1222-1226$. DOI: $10.14199 / \mathrm{ppp}-2012-210$ 